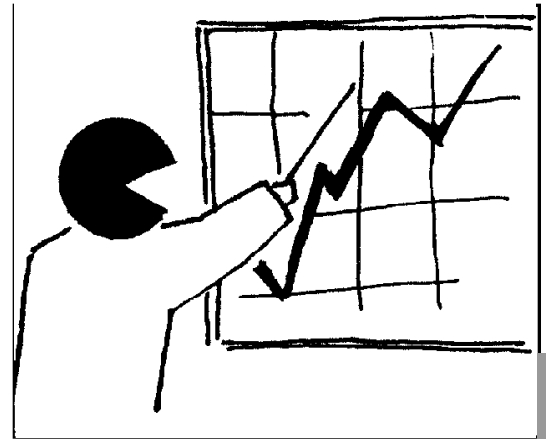

МЕТОДИКА НАВЧАННЯ I ВИХОВАННЯ

УДК 81.271.12

ЖАННА БАБ'ЯК, к.п.н., доч., завідувач кафедри украӥнської та іноземних мов ТНТУ імені І. Пулюя;

ЛІЛІАНА ДЖИДЖОРА, ст. викладач кафедри украӥнської та іноземних мов ТНТУ імені І. Пулюя;

ОЛЬГА ПЕРЕНЧУК, ст. викладач кафедри української та іноземних мов ТНТУ імені І. Пулюя

\title{
ВИКОРИСТАННЯ МАТЕРІАЛІВ НА ЗАНЯТТЯХ ЕSР: АВТЕНТИЧНІ ЗАВДАННЯ ЧИ ТРАДИЦЙНІ ПІДРУЧНИКИ
}

\author{
JANNA BABIAK, PhD (Pedagogics), Ass. Prof., Head of the Department \\ of Ukrainian and English languages of TNTU named after I.Puluj; \\ LILIANA DZHYDZHORA, Senior Lecturer of the Department of Ukrain- \\ ian and English languages of TNTU named after I.Puluj; \\ OLGA PERENCHUK, Senior Lecturer of the Department of Ukrainian \\ and English languages of TNTU named after I.Puluj
}

\section{МОДЕЛЬ ПІДВИЩЕННЯ КВАЛІФІКАЦІЇ ПЕДАГОГІЧНИХ ПРАЦІВНИКІВ ЗА ОЧНО-ДИСТАНЦІЙНОЮ ФОРМОЮ НАВЧАННЯ}

Стаття має на меті проаналізувати та порівняти використання автентичних матеріалів і традиційних підручників на заняттях ESP. Автори порівнюють переваги і можливі недоліки обох типів матеріалів. У статті також йдеться про ставлення і преференції викладачів ESP щодо доцільності вибору того чи іншого матеріалу. 3 цією метою авторами було проведено соціологічне дослідження із залученням викладачів ESP кафедри української та іноземних мов Тернопільського національного університету імені І. Пулюя. У статті робиться спроба розробити деякі рекомендації стосовно вибору навчального матеріалу для занять ESP.

Ключові слова: автентичні матеріали, англійська мова професійного спрямування, підручник, викладання, вивчення, внутрішні джерела, зовнішні джерела.

(C) Ж. Баб'як, Л. Джиджора, О. Перенчук
Summary. The purpose of the article is to analyze and compare the use of authentic materials and textbooks in English for Specific Purposes learning and teaching context. The authors compare the benefits and possible drawbacks of both types of materials. The article focuses on teachers' attitude and opinions regarding the appropriateness and exploitability of each source and their preferences and reasons for materials selection. A specially designed questionnaire was conducted, addressing the questions of materials selection, teachers' preferences regarding authentic materials or textbooks and selection criteria applied by the ESP lecturers of I. Puluj TNTU. The authors made an attempt to offer some recommendations regarding materials selection in ESP setting.

Key words: authentic materials, English for Specific Purposes (ESP), textbook, teaching context, learning context, internal sources, external sources.

Постановка проблеми в загальному вигляді. Одним із найважливіших завдань у складанні навчальної програми курсу ESP $є$ вибір навчальних матеріалів. Часто викладач стоїть перед дилемою: працювати з підручником, написаним для окремого напряму ESP (економістів, інженерів, медичних працівників і т. п.), узяти за основу автентичні матеріали, пов'язані з певною галуззю знань (документи, угоди, ділові листи, таблиці, графіки, інструкції з використання та інше), або поєднувати ці різні типи матеріалів. Питання в тому, що $\epsilon$ кращим вибором для занять ESP. Чи можемо ми покладатися лише на підручник, чи застосовувати наші вміння і досвід як викладачів ESP у виборі автентичних матеріалів? Що відповідатиме краще потребам студентів і навчальному процесу загалом? 
Отже, ми маємо на меті проаналізувати й порівняти використання автентичних матеріалів і традиційних підручників на заняттях ESP, порівняти переваги і можливі недоліки обох типів матеріалів. На основі проведеного анкетування викладачів кафедри УІМ ТНТУ ім. І. Пулюя розробимо ряд рекомендацій з використання того чи іншого типу навчального матеріалу.

Аналіз досліджень і публікацій. У сучасному світі чітко окреслилися дві тенденції у навчанні іноземних мов: традиційне навчання, коли ставиться мета наблизитися до рівня носія мови, що вивчається, та навчання іноземної мови для професійного спілкування. Традиційним навчанням іноземної мови опікуються фахівці, які готують учителів та викладачів іноземних мов і перекладачів. Методика підготовки таких фахівців має багатолітню історію та значні досягнення.

Більш перспективною для сучасного глобалізованого суспільства $\epsilon$ порівняно молода методика навчання іноземних мов для професійного спілкування, яка розпочала інтенсивний розвиток 3 кінця ХХ століття. У європейських вишах спеціальні курси англійської мови для медичних працівників, юристів, підприємців, спеціалістів IT сфери, туристичної галузі тощо розробляються та проводяться 3 кінця 80-х років минулого століття. В Україні методикою навчання іноземних мов для професійного спілкування, зокрема, юристів, фахівців 3 технічних спеціальностей, економістів, медиків, військових науковці зацікавилися дещо пізніше (Л. Морська, Г. Савченко, О. Тарнопольський, І. Чірва та інші) [1]. Методикою навчання іноземних мов для професійного спілкування займаються переважно викладачі немовних вишів, мовних курсів та індивідуальні викладачі іноземних мов, які працюють безпосередньо на робочому місці замовника. Кваліфікованих фахівців з такої методики ще надто мало, і це $\epsilon$ нагальною проблемою.

Оскільки саме ESP найповніше відповідає потребам міжнародного спілкування у професійному середовищі, забезпечує достатній лексичний і граматичний мінімуми фахівцеві, необхідний темп і плинність мовлення, вона $є$ надзвичайно важливою для виконання посадових обов'язків як керівниками, так і рядовими працівниками транснаціональних компаній. ESP задовольняє не лише потреби усного, але й письмового, відео- та віртуального спілкування 3 використанням інформаційно-комунікаційних і мобільних технологій i пристроїв.

У навчанні ESP поєднуються педагогічні принципи ораторського мистецтва та вміння ініціювати й підтримувати розмову, володіння комп'ютерними технологіями, програмним забезпеченням, починаючи 3 техніки письма та закінчуючи комп'ютерним дизайном. Професійне спілкування сьогодні вимагає високої технічної компетенції фахівця. Професійні комунікатори використовують різноманітні стратегії, методики і технології для успішного ведення бізнесу, тому що в усіх його видах потрібно користуватись читанням, письмом, редагуванням, усним мовленням, програмним забезпеченням, комп'ютерною графікою, Інтернетом, мобільними технологіями тощо. Підготовка таких професійних комунікаторів $€$ одним із завдань іншомовної освіти в епоху глобалізації, оскільки саме вони зможуть вивести бізнес на якісно новий науково обгрунтований рівень 3 урахуванням культурних особливостей населення i технологічних можливостей $[9, c$. 13].

Саме 3 огляду на сказане вище роль навчальних матеріалів у викладанні та вивченні ESP має надзвичайно велике значення, а їх вибір впливає на загальний успіх у володінні мовою. Відомі британські фахівці 3 методики викладання англійської мови для спеціальних цілей (ESP) T. Дадлі-Івенс і М. Сейнт Джон [3, c.170-171] виділяють наступні функції навчальних матеріалів на заняттях ESP:

- джерело мови;

- основа для вивчення мови;

- мотиватор і стимулятор навчання;

\section{- довідкова література.}

У контексті самого процесу навчання, коли спілкування англійською не $\epsilon$ середовищем і англійську мову вивчають як іноземну, матеріали, зазвичай, $є$ тим рідкісним джерелом мови, що не завжди доступне для студентів. Хоча спілкування в аудиторії $\epsilon$ головним джерелом вивчення мови, але завдяки соціальним мережам, засобам масової інформації і зв'язку сьогодні проблема 3 матеріалами практично вирішена.

Дадлі-Івенс і М. Сейнт Джон [3, c.171] вважають, що, "будучи основою для вивчення, навчальні матеріали повинні бути надійним джерелом, тобто робочими, послідовними і впізнаваними". Однак, вони не є категоричними щодо фіксованого формату навчальних матеріалів. Більше того, автори наголошують на необхідності стимулювання пізнавального процесу і розвитку у студентів відчуття їх прогресу.

Дослідники [3, c.171] дають характеристику матеріалам наступним чином: "щоб стимулювати і мотивувати, матеріали повинні бути складними і досяжними водночас, пропонувати нові ідеї та інформацію, але базуватись на отриманому досвіді і знаннях студентів, розвивати інтерес і творчість" [3, c.171]. Крім того, матеріали повинні містити щось нове для аудиторії, беручи до уваги іiї потреби і зв'язок з реальним життям.

3 метою самостійного вивчення або використання як довідкової літератури, матеріали повинні бути впорядковані, систематизовані і зрозумілі. Різноманітні пояснення, приклади з теми, практичні завдання обов'язково мають бути присутні, так само як і ключі до завдань.

Виклад основного матеріалу дослідження. 3 цих причин давайте розглянемо потенційні переваги та недоліки використання автентичних матеріалів. Перш за все, необхідно дати визначення понять "автентичний" i "автентичні матеріали". Відомий британський практикуючий викладач ESP Алекс Гілмор [6] стверджує, що автентичність стосується:

мови, яка продукується і використовується носіями в мовній спільноті;

мови, яка продукується реальним спікером чи автором для реальної аудиторії з метою донести якийсь реальний меседж;

певних характеристик, наданих тексту/меседжу слухачем або читачем;

взаємодії між студентами і викладачами;

поставлених завдань;

оцінювання;

культури і здатності адаптуватися до цільової аудиторії;

соціальної ситуації в аудиторії.

Гілмор описує ряд розбіжностей між автентичною мовою і мовою підручників, і достатньо переконливо аргументує на користь автентичних матеріалів, стверджуючи, що ос- 
танні є "значно багатшим джерелом знань для тих, хто вивчає мову, і мають величезний потенціал для використання різноманітними шляхами i на різних рівнях, щоб розвивати комунікативну компетенцію тих, хто вивчає мову" [6]. На його думку, автентичні матеріали дають безліч можливостей для розробки завдань $\mathrm{i}$ різноманітних видів діяльності. Гілмор визначає автентичне завдання як таке, "що виконується в аудиторії і має всі характерні риси реального завдання (іншими словами, завдання, узяті з реального життя), яке може виконуватись поза межами аудиторії, тобто не $з$ метою кращого засвоєння мовного матеріалу, де мова $\epsilon$ лише інструментом виконання поставленого завдання" [5]. Найкращими прикладами автентичних завдань $\epsilon$ робота над проектом, групова презентація, проведення соціологічних опитувань.

Варто зазначити, що оскільки головною метою використання навчальних матеріалів на заняттях ESP $\epsilon$ створення потенційних можливостей для практичної взаємодії, відповідного і мотивуючого мовного середовища, саме автентичні тексти, документи та інші матеріали є основою для досягнення цієї цілі. Вони забезпечують студентів змістовим контекстом, автентичним і потрібним словником, виступають зв'язуючою ланкою між майбутнім фахом. Такі матеріали включають автентичні тексти з певної галузі знань, статті з фахових журналів, візуальні матеріали, різноманітні форми і документи, інструкції та інше.

Використання автентичних текстів фахового спрямування сприяе засвоєнню майбутніми фахівцями відповідної фахової лексики, використання певних граматичних конструкцій у побудові речень. Іноземна мова професійного спрямування у вищій школі не передбачає вивчення граматичних категорій у межах окремої теми навчальної програми, а лише опосередковано через тексти та завдання фахового спрямування. Опрацьовуючи текст та виконуючи відповідні завдання, студенти мають можливість тренувати свою зорову пам'ять і навички письма, що є також надзвичайно важливим у професійній підготовці. Добірку фахових текстів здійснює викладач, який спрямовує навчальний процес на заняттях, проте можна давати завдання студентам шукати цікаву інформацію на задану тематику в мережі Інтернет у рамках виконання ними самостійної роботи. Звичайно, необхідно мотивувати їх додатковими балами, проте такий вид діяльності є однаково корисним і викладачам-предметникам, які мають можливість відчути новий свіжий погляд молоді на ту чи іншу проблему, і студенти отримують можливість навчитися шукати необхідну інформацію в мережі Інтернет, аналізувати, вибирати найнеобхідніше, навчитися презентувати інформацію іноземною мовою тощо.

3 метою налагодження стосунків та порозуміння між представниками різних культур і національностей ми наголошуємо на ефективності застосування автентичних аудіоматеріалів, які демонструють особливості вимови, акцент та ритм спілкування носіїв мови. Звичайно, аудіювання не є легким завданням для студентів 3 низьким рівнем володіння мовою, однак не варто нехтувати цим ефективним методом формування комунікативної компетенції майбутніх фахівців. Викладач повинен підбирати аудіоматеріал таким чином, щоб усі учасники навчального процесу розуміли суть, а завдання до прослуханого матеріалу необхідно розробляти відповідно до рівня знань (достатній, середній, високий).

Незважаючи на таку важливу роль автентичних матеріалів на занятTяx ESP, потрібно акцентувати на потенційних ризиках у цьому процесі. У першу чергу, мусимо нагадати, що переважна більшість автентичних текстів не була написана саме 3 метою вивчення мови. І як результат, такі матеріали можуть стати або занадто складними або, навпаки, занадто легкими для цільової аудиторії. Окрім того, застосування їх часто вимагає великих зусиль з боку викладача у здійсненні пошуку, розробки відповідних граматичних та лексичних завдань, наближення матеріалів до навчальних цілей і часових рамок аудиторної форми заняття. Саме тому іноді виникає питання про доречність використання автентичних матеріалів у типовому занятті ESP або GE навчальному контексті.

Застосування підручників для занять ESP, також має свої переваги та недоліки. Для початку згадаймо, що Хатчінсон і Торрес [7] наполягають на необхідності працювати з підручником, оскільки саме він $\epsilon$ тією структурою, яка слугує надійним базисом для розвитку автономії учнів. Таким чином, відбувається взаємодія між учнями, учителем і матеріалами. Ансарі і Бабаіі з числа тих авторів, котрі також схиляються на користь використання підручників на заняттях 3 вивчення іноземної мови, аргументуючи свою думку певними переконаннями:

- підручник несе в собі ціль вивчення і учні сприймають сам процес навчання відповідально;

- підручник сам по собі є навчальною програмою;

- підручник містить уже готові тексти і завдання [2].

Насамперед, більшість авторів звертають увагу на той факт, що підручник є надзвичайно потрібним i корисним для викладачів-початківців, при цьому виділяючи деякі важливі моменти при виборі підручників: зміст, рівень, обсяг, ціна, практичне застосування запропонованого матеріалу і т. і. [7, с. 127]. Адекватний підручник на заняттях ESP $\epsilon$ готовим джерелом матеріалів і видів діяльності, а також визначає мету i завдання для студентів. Підручники зазвичай містять актуальні і потрібні теми для дискусій, необхідний словниковий набір, мінімум граматичного матеріалу, який украй важливий у рамках вибраних тем.

Серед аргументів не на користь підручників, мабуть, найголовнішим $\epsilon$ те, що практично неможливо підібрати такий, який відповідав би потребам усієї групи та рівню їх підготовки. Більшість груп змішані, оскільки студенти вивчали мову в різних закладах освіти і за різними матеріалами. Окрім того, учителі іноді перебільшують роль підручника і приділяють недостатньо уваги творчим завданням та індивідуальному підходу до викладання. А якщо розглянути підручники для студентів комп'ютерних, економічних спеціальностей, то тут ми маємо справу із застарілими темами і вже не актуальними текстами.

Ще однією перешкодою при виборі самого підручника може стати його вартість і не завжди доступність. Саме $з$ цих причин більшість авторів та й, особливо, практикуючих викладачів ESP доходять висновку, що потрібно поєднувати зовнішні (підручники) і внутрішні (ресурси самого навчального закладу) джерела

У сучасному світі постійних змін на перший план постає актуальність інформації. Оскільки саме Інтернет відповідає вимогам швидкості та ак- 
туальності інформації, він став невід'ємною складовою сучасного навчального процесу. Інтернет, наповнений великою кількістю автентичних матеріалів (тексти, аудіо, відео і т. п.), надає можливість пошуку інформації відповідно до тем. Програмні продукти і платформи створюють іншомовне професійне середовище для обміну ідеями, що надто важливо для тих, хто вивчає іноземну мову для конкретних професійних цілей (ESP). Таким чином, основним завданням бачиться вміння пошуку й аналізу необхідних матеріалів.

Деякі навчальні посібники містять додаткові тексти, наприклад, для загально-технічної англійської мови. Однак студенти, котрі вивчають професійну іноземну мову, часто мають більш різноманітні і специфічні потреби. У таких випадках стають у нагоді доступні онлайн-матеріали. Багато сучасних підручників розміщують веб-посилання 3 певної тематики. Наприклад, книга для викладача курсу Technical English містить посилання на інтернет-ресурси в кожному розділі. До процесу пошуку матеріалів 3 певної теми охоче долучаються студенти, що може бути представлено як спільна робота над проектом.

Такі технології дозволяють зануритись у професійне середовище не тільки у процесі спілкування, а і 3 метою створення матеріалів для занять. Чим більше навчальна ситуація наближена до реальної, тим вищою буде мотивація у студентів. Викладачі та заклади вищої освіти, які інтегрують інтернет-технології в курси англійської мови професійного спрямування, можуть стикатися 3 такими проблемами, як: доступ, наявність та надійність технології; потреба в постійному тренінгу викладачів і студентів; різні рівні технічної самостійності викладачів і студентів; час та ресурси, необхідні для створення інтегрованих навчальних курсів; потреба в нових способах проведення занять, де використовуються інтернет-технології, у тому числі вирішення технічних проблем під час заняття; адаптація до змінюваної ролі викладача і студентів, особливо в онлайнових курсах тощо. Ці питання потрібно ретельно продумати, щоб забезпечити безперебійну та успішну інтеграцію інтернет-технологій для того, щоб викладачі і студенти сприймали використання цих технологій як необхідне доповнення до курсу 3 вивчення англійської мови професійного спрямування.

Беручи до уваги всі згадані вище аргументи "за" і "проти", пов'язані 3 вибором матеріалів на заняттях ESP, ми вирішили провести експеримент 3 викладачами ESP кафедри української та іноземних мов ТНТУ імені I. Пулюя. Методом дослідження було анонімне соціологічне опитування, яке містило наступні запитання:

1. Чи вважаєте ви матеріали і процес їх вибору важливими в ESP?

2. Чи використовуєте підручник на заняттях ESP? Вкажіть переваги або недоліки.

3. Чи застосовуєте автентичні матеріали на заняттях ESP? Вкажіть переваги або недоліки.

4. Чи поєднуєте ви підручник з автентичними матеріалами на заняттях ESP? Вкажіть переваги або недоліки.

5. Що є для вас головною перешкодою (негативним моментом) у виборі навчальних матеріалів?

У дослідженні взяли участь 14 викладачів ESP віком від 30 до 60 років, стаж викладання яких саме ESP приблизно однаковий - 10-15 років, хоча загальний стаж роботи на кафедрі доволі різний. Усі викладачі викладають дисципліну ESP для всіх спеціальностей комп'ютерного, економічного, інженерного напрямів на чотирьох факультетах університету. Варто зазначити, вони дали відповіді на поставлені запитання, що відобразило реальну картину їхнього бачення i преференцій стосовно вибору матеріалів для занять. Маємо визнати, що всі респонденти викладачі переконані у важливості вибору навчальних матеріалів для ESP з метою ефективного процесу навчання. Стосовно використання традиційних підручників викладачі віддають перевагу все-таки роботі з базовим підручником серії "English for", хоча зауважують, що іноді ESP підручники містять застарілі або надто легкі тексти, особливо ті, що розроблені для комп'ютерних спеціальностей. Головним недоліком використання підручників визнано той факт, що надзвичайно складно підібрати підручник, який відповідав би потребам і рівням усіх студентів групи.

До критеріїв відбору автентичних матеріалів переважна більшість викладачів віднесла відповідність мовній тематиці і потребам студентів. Це стосується як візуальних засобів (різноманітні відео, таблиці, графіки, схе- ми та інше), так і письмових матеріалів (газетно-журнальні публікації, інтернет-видання, зразки контрактів, ділових листів, нормативно-правових документів та інше). Переважна більшість викладачів визнала, що такі матеріали позитивно сприймаються студентами.

Висновки та перспективи подальших досліджень. Опираючись на літературні джерела та проведене опитування серед викладачів ESP, ми доходимо певних висновків і пропонуємо рекомендації стосовно вибору навчального матеріалу для підвищення ефективності самих занять та процесу навчання мови загалом.

У випадку, коли підручник $є$ основним навчальним матеріалом для певної групи ESP, потрібно врахувати кілька важливих критеріїв його вибору. Зокрема, він має відповідати головній меті і завданням навчального процесу, крім цього, і певному рівню володіння мовою. Нарешті, підручник мусить бути доступним як для викладачів, так і для студентів 3 огляду на його вартість та наявність.

Автентичні матеріали покликані розвивати чотири мовних умінь: слухання, говоріння, читання і письмо. 3 цією метою їх потрібно адаптувати і використовувати відповідно до потреб конкретної групи. Варто зазначити, що і спеціалісти з певної галузі знань, і самі студенти є джерелом навчальних матеріалів.

Отже, на даний час не існує ідеального універсального підручника ESP або іншого навчального матеріалу. Тому пошук необхідних навчальних матеріалів $\epsilon$ безперервним процесом, у якому ці матеріали потрібно постійно оновлювати, адаптовувати й розробляти. А найбільш ефективним вважаємо поєднання базового ESP підручника і автентичних матеріалів у контексті вивчення ESP.

\section{ЛІТЕРАТУРА}

1. Александров В. М. Методика інтенсивного навчання інженерів професійно-орієнтованої англійської мови: автореф. дис. ...канд. пед. наук: 13.00 .02 / В. М. Александров. Одеса, $2009.24 \mathrm{c}$.

2. Ansary, H., \& Babaii, E. "Universal characteristics of EFL/ESL textbook: A step towards systematic textbook evaluation" The Internet TESL Journal, Vol. 8. 2002. № 2. Pp 1-8.

3. Dudley-Evans, T. and Maggie Jo St John. Developments in ESP (A multi- 
disciplinary approach) / Dudley Evans, T. and Maggie Jo St John. Cambridge: Cambridge University Press, 1998. $301 p$.

4. English for Specific Purposes (ESP) in Ukraine. A Baseline Study / Astanina, N., H. Bakaieva, I. Beliayeva, A. Boiko, O. Borysenko, N. Cherkashina, N. Filippova, A. Khodtseva, L. Klymenko, S.Kostrytska, T. Kozymyrska, I. Shevchenko, T.Skrypnyk, N. Todorova and I. Zuyenok. 2004. Kyiv: Lenvit. 122 p.

5. Gilmore, A. A comparison of textbook and authentic interactions. ELT. 2004. Journal 58/4. Oxford University Press.

6. Gilmore, A. "Authentic materials and authenticity in foreign language learning". Language Teaching. 2007. Vol. 40(02). P. 97-118. Doi:10.1017/ S0261444807004144

7. Hutchinson, T. and Torres, E. The Textbook as Agent of Change. ELT. 1994. Journal. Vol. 48. No 4. P. 315-328.

8. Jordan, R. English for Academic Purposes: A guide and resource book for teachers. Cambridge: Cambridge University Press, 1997.

9. Knight J. Five Truths about Internationalization. International Higher Education. Jane Knight / Boston College Magazine. 2012. № 69. URL: www.bc.edu/cihe.

10. Lee W. Authenticity revisited: Text authenticity and learner authenticity. ELT Journal. 1995. Vol. 49. № 4. P. 323-328.

11. MacDonald M. N., Badger R., Dasli M. Authenticity, culture and language learning. Language and Intercultural Communication. 2006. Vol.
6(3/4). P. 250-261.

12. Swales, J. (1980) ESP-The textbook problem. English for Specific Purposes (ESPJ). Vol. 1. P. 11-23.

13. Tariq Mahmood Khan, Ghulamullah, M. Naeem Mohsin, Ashig Hussain Dogar and Ahmed Sher Awan. Needs Analysis of English for Occupational and Specific Purposes: International Journal of Social Sciences and Education. 2011. Vol. 1. Issue 4. P. 632-643.

\section{REFERENCES}

1. Aleksandrov V. M. Metodyka intensyvnoho navchannya inzheneriv profesiyno-orientovanoi angliyskoi movy: autoref. disser. ... cand. ped. nauk: 13.00.02. Odessa, 2009. $24 \mathrm{~s}$.

2. Ansary, H., \& Babaii, E. "Universal characteristics of EFL/ESL textbook: A step towards systematic textbook evaluation" The Internet TESL Journal, Vol. 8. 2002. № 2. Pp 1-8.

3. Dudley-Evans, T. and Maggie Jo St John. Developments in ESP (A multidisciplinary approach) / Dudley Evans, T. and Maggie Jo St John. Cambridge: Cambridge University Press, 1998. 301 p.

4. English for Specific Purposes (ESP) in Ukraine. A Baseline Study / Astanina, N., H. Bakaieva, I. Beliayeva, A. Boiko, O. Borysenko, N. Cherkashina, N. Filippova, A. Khodtseva, L. Klymenko, S.Kostrytska, T. Kozymyrska, I. Shevchenko, T.Skrypnyk, N. Todorova and I. Zuyenok. 2004. Kyiv: Lenvit. 122 p.

5. Gilmore, A. A comparison of textbook and authentic interactions.
ELT. 2004. Journal 58/4. Oxford University Press.

6. Gilmore, A. "Authentic materials and authenticity in foreign language learning". Language Teaching. 2007. Vol. 40(02). P. 97-118. Doi:10.1017/ S0261444807004144

7. Hutchinson, T. and Torres, E. The Textbook as Agent of Change. ELT. 1994. Journal. Vol. 48. No 4. P. 315-328.

8. Jordan, R. English for Academic Purposes: A guide and resource book for teachers. Cambridge: Cambridge University Press, 1997.

9. Knight J. Five Truths about Internationalization. International Higher Education. Jane Knight / Boston College Magazine. 2012. № 69. URL: www.bc.edu/cihe.

10. Lee W. Authenticity revisited: Text authenticity and learner authenticity. ELT Journal. 1995. Vol. 49. № 4. P. 323-328.

11. MacDonald M. N., Badger R., Dasli M. Authenticity, culture and language learning. Language and Intercultural Communication. 2006. Vol. 6(3/4). P. 250-261.

12. Swales, J. (1980) ESP-The textbook problem. English for Specific Purposes (ESPJ). Vol. 1. P. 11-23.

13. Tariq Mahmood Khan, Ghulamullah, M. Naeem Mohsin, Ashig Hussain Dogar and Ahmed Sher Awan. Needs Analysis of English for Occupational and Specific Purposes: International Journal of Social Sciences and Education. 2011. Vol. 1. Issue 4. P. 632-643.

Стаття надійшла 30.03.2019 p. 